\title{
THE BALANCE SHEET, INFORMATION SOURCE FOR DETERMINING THE FINANCIAL POSITION OF ENTITIES LISTED AT THE STOCK EXCHANGE IN BUCHAREST
}

\author{
Teodor Hada ${ }^{1}$ \\ Teodora Maria Avram ${ }^{2}$
}

\begin{abstract}
The present paper presents aspects related to the financial position of 74 companies listed at the Stock exchange in Bucharest. Different points of view regarding the connection between the balance sheet and the financial position of economic entities in general are presented along the first part of the paper. To continue, we presented a case study about the balance sheet elements for entities rated at the Stock Market in Bucharest, according to the stock capitalization of Top 100 issuers. Based on data from the 2011 balance sheet, certain structure rates of assets and liabilities were determined. The values obtained as a result of structure rate calculation were compared to the normal values from the industrial branch. Conclusions focus on determining the financial position of elements from the balance sheet for the presented economic entities.
\end{abstract}

Key words: balance sheet, structure rates, financial position, analysis, The Bucharest Stock Exchange.

JEL Code: $M 41$.

\section{Introduction}

By this study, we followed as objective, based on data from the patrimonial balance sheet, to determine the financial position of unities listed at the Stock Exchange in Bucharest, as well as to count deviations from the indicators normal limits, determined both for assets and for liabilities.

The analysis was made for the economic enterprises listed at the Stock Exchange in Bucharest, excluding banks. Enterprises listed at the Stock Exchange in Bucharest were selected according to the stock capitalization indicator from Top 100 (www.bvb.ro, emitent statistics).

The paper elaboration methodology supposed choosing the theme, documentation, collecting the information, comparing data as well as the financial analysis. Choosing the theme "The Balance Sheet, Information Source for Determining the Financial Position of Entities Listed at the Stock Exchange in Bucharest", is based on the importance of the balance sheet as information source for establishing the financial position in any economic entity, because the balance sheet represents "the symbol of accountancy and the centre of financial analysis" (M. Ternisien, 1992, 1). The content of the paper has a bibliographical documentation, shown along the first part of the paper, where we can see the different points of view of certain authors about the balance sheet and the financial position. It also has a practical documentation, shown in the case study, based on real foundations, where, in order to obtain the financial situations of the 74 enterprises for which we made the documentation, we found the Bucharest Stock Exchange website useful indeed. Data were collected from Top 100 of issuers according to capitalization (Ibidem), and for theoretical and practical approaches, we used the special literature, normative acts and annual financial situations. The comparison was made, in the case of structure rate results, with the corresponding normal values from the industrial branch. The analysis of the financial position had as main objective the research of causes and effects characterizing the financial position.

\footnotetext{
1 “1 Decembrie 1918” University of Alba Iulia, e-mail: teohada@yahoo.com

2 "1 Decembrie 1918" University of Alba Iulia.
} 
In relation to bibliographic references presented at the end of the study, we emphasized the status of knowledge in the documentation about appreciating the financial position of enterprises, based on the structure of the balance sheet assets and liabilities.

\section{Determining the Structure Rates of Assets and Liabilities}

The relation between the balance sheet and the financial position of enterprises is approached in the special literature. To continue, we present a few points of view, as follows:

Rusalim Petriş, in the paper "Bazele contabilității" ("Bases for Accountancy"), (breviary), edi $\square$ ia a III-a, Publishing House Gorun, Iaşi, 2000, p.13, considers that the balance sheet is "the synthesis of accountancy presenting, at a certain given moment, the economic-financial situation, expressed in money, of a value movement ambit, placing the assets and liabilities face to face".

According to the Public Finance Ministry Order no. 3055/2011, "Accountancy Regulations in Agreement to Directive IV of European Economic Communities", the balance sheet is the synthesis accountancy document by which the assets, debts and equities of the entity at the end of the financial exercise are presented, as well as other situations provided by law.

For Monica Violeta Achim "the financial position of an entity is represented by the relation between assets, debts and equities"( Monica Violeta Achim, , 2009, p.199).

Maria Berheci, in the paper "Valorificarea raportărilor financiare. Sinteze contabile: teorie, analize, studii de caz" ("Capitalization of Financial Reports. Accountancy Synthesis: Theory, Analysis, Case Studies"), Publishing House CECCAR, Bucureşti, 2010, p. 317, considers that "the financial position is influenced, in a favourable or unfavourable direction, by a series of factors, namely technical economical factors, legal factors, strategic and circumstantial factors. In monetary terms, the financial position reflects the difference between assets and debts, and all these factors have an incidence, which might be financially compared.

Iulia Jianu, considers that the balance sheet shows "the financial position of the enterprise only at a given time, respectively at the end of the financial exercise, nevertheless, this financial position is the consequence of results obtained by the enterprise starting with its foundation time until the date of the balance sheet. The balance sheet shows how the manager of the company invested and where the money comes from. Similarly, the balance sheet supplies information about return rates, capital structuring, the enterprise liquidity and flexibility"( Iulia Jianu, 2007, p.195).

Romanian regulations state: "official documents used for presenting the economic- financial situation are annual situations, which must provide an accurate image of the financial position, of financial performance and the other information referring to the carried out activity"(The Accounting Law no. 82/1991, republished and added).

In contrast to the above mentioned, we show that the financial position may be determined based on elements from the balance sheet assets and liabilities, by comparing them with the normal values of enterprises from developed market economies. The financial situations were considered for the year 2011 excepting Titan S.A (MPN) having the indicators in 2010 as, at the moment of extracting data, these were not published for the year when the study was realized. They were also considered for an economic entity, namely Mecanica Ceahlău (MECF), where the assets are not equal to the liabilities, so that for this entity calculations were not made.

\section{Determination of Assets Structure Rates and Determination of the Financial Position in Comparison with Normal Values of the Structure Rates in Industry.}

For determining the structure of assets, in the study, we chose a number of 74 enterprises, according to the Top 100 issuers by capitalization, listed at the Bucharest Stock Exchange. The assets structure rates constitute an information source for investors on the Bucharest Stock Exchange. 
To continue, we will determine the structure rates of the assets for the year 2011, based on annual financial situations, expressed in lei, belonging to enterprises representing the object of the study (see annex no. 1)

The enterprises financial position is determined according to their position towards the normal values for the industrial branch, each having a calculation modality.

The non-current assets reflect the investment degree of the enterprise capital. The rapport growth might be interpreted as favourable, as long as we may register an increase in the turnover. The calculation modality of non-current assets is:

$$
\text { Non-current assets rate }=\frac{\text { Non }- \text { currentAssets }}{\text { TotalAssets }} \times 100
$$

The current assets rate express the share of current rates in total assets. This indicator depends on the entities activity sector. In industry, this share, the closer to $40 \%$ it is, the better. The growth is interpreted positively, but the components of the current assets must be taken into consideration

$$
\text { The current assets rate }=\frac{\text { CurrentAssets }}{\text { TotalAssets }} \times 100
$$

The rate of expenses in advance is determined as follows:

$$
\text { The rate of expenses in advance }=\frac{\text { ExpensesInAdvance }}{\text { TotalAssets }} \times 100
$$

Between the three structure rates of the assets, determined in table 1 there is a correlation, in the sense that the sum of all three must give a total of $100 \%$. We may observe the fact that, in the case of non-current assets, the best share from the 74 economic entities belongs to OIL TERMINAL S.A. (OIL) with a 95,65\% share, and the smallest value is registered by PETROLEXPORTIMPORT S.A. (PEI) holding a share of $15,94 \%$, thus, the difference is very big, especially if we relate only to the rate of tangible assets, which should come closer to $60 \%$.

Similarly, the rate of current assets approaches the normal values in a share small enough, of 17 economic units out of 74, the total ones. A good share of 40,12\% is registered by STIROM S.A. Bucharest (STIB) and 36,81\% the share registered by ALRO S.A. (ALR). SINTEZA S.A. (STZ) holds worrisome values with only $3,83 \%$ and CEMAN S.A. Zalău (CEON) with $6,87 \%$.

From the determined structure rates, we may observe that in a greater extent, the bigger share is held by non-current assets, a fact showing that the majority of entities have an increased flexibility, and the smallest share is held by the in advance-expenses.

2.2 Determination of Liabilities Structure Rates and Determination of the Financial Position in comparison to Normal Values of the Structure Rates in industry.

In the same way we determined the structure of assets, for determining the liabilities, we considered the same enterprises, in number of 74, according to the Top 100 issuers by to capitalization, listed at the Bucharest Stock Exchange, with the help of liabilities structure rates, representing a source wherefrom investors on the Bucharest Stock Exchange may obtain information.

Thus, we will determine the liabilities structure rates, expressed in lei, for the year 2011, based on annual financial situations of enterprises representing the object of study. 
The determination of the enterprises financial position is realized according to their position towards the normal values for the industrial branch, each having a specific calculation modality.

The rate of global indebtedness reflects the entities financial dependence degree. It is a financial risk indicator, which should register values less than $66 \%$ and should find itself in a decrease, in order to appreciate the enterprises situation favorably. The indicator growth reflects a favorable situation only if the indebtedness exercises an effect of positive leverage for entities and if current debts grow as a follow up of commercial credits granted by suppliers.

$$
\text { The rate of global indebtedness }=\frac{\text { TotalDebts }}{\text { TotalLiabilities }} \times 100
$$

The rate of global financial autonomy signifies the entities financial independence degree, which should register greater values than $33 \%$ in order to ensure the premise of the entities financial autonomy.

$$
\text { The rate of global financial autonomy }=\frac{\text { Equities }}{\text { TotalLiabilities }} \times 100
$$

The commissions rate is determined as follows:

$$
\text { The commissions rate }=\frac{\text { Commissions }}{\text { TotalLiabilities }} \times 100
$$

The rate of in-advance incomes is calculated according to the formula:

$$
\text { The rate of in-advance incomes }=\frac{\text { In-advanceIncomes }}{\text { TotalLiabilities }} \times 100
$$

The four liability structure rates, determined in table 2 depend one on the other, in the sense that they form a unitary whole of $100 \%$. The rates of global indebtness are normal for most companies, under $66 \%$, the normal value in industry, 60 economic entities have normal values and thus, the respective economic entities have a favourable situation. Among these, we may enumerate S.C. TRANSILVANIA CONSTRUC $\square$ II S.A. (COTR) with a $27,73 \%$ share, TMK-ARTROM S.A. (ART) with $51,88 \%$ and C.N.T.E.E TRANSELECTRICA (TEL) which has $44,75 \%$. Un unfavourable situation is that of ROMPETROL RAFINARE S.A. (RRC) having 100,83\% share and MECHEL Târgovişte S.A. (COS) with 118,09\%.

The rate of global financial autonomy is a favourable one for 59 economic units having over $33 \%$, as VRANCART S.A. (VNC) having 55,84\% share or MEFIN S.A. (MEF) having 85,89\%. Still, there are a few enterprises having less than $33 \%$ share, as ARMATURA S.A. (ARM) having only $0,62 \%$ or OLTCHIM S.A. Rm. Vâlcea with a very low share $-37,61 \%$, these shares being very low, they cannot ensure the premise of the entity's financial autonomy, a premise that is supposed to exist for all economic entities.

Once the liability structure rates are determined, we may observe at first sight that the global financial autonomy rate, respectively the equities, holds the biggest share out of the total. (Anexa 1)

\section{Conclusions}

Taking into consideration the investors' interest for buying and selling shares on the Bucharest Stock Exchange, the presented data are an important source for investment decisions. Thus, information about the financial position of an entity is offered to us by the balance sheet, as a document of accounting synthesis. The financial position of enterprises may be considered as being an activity that may be realized with the help of the patrimonial balance sheet. As we have seen in the real study, shown in tables 1 and 2, the financial position is calculated with the help of assets and liabilities structure rates. 
From the data presented in the case study at the Bucharest Stock Exchange, for the 74 enterprises, according to Top 100 issuers after capitalization, the assets structure rates have registered in the greatest share values that cannot be included within the normal limit. For example, the floating assets rate must be as close to $40 \%$, however, in the case of CALIPSO S.A. Oradea (CAOR) the share is only of 12,69\%. Similarly, we have ELECTROARGE $\square$ S.A. Curtea de Argeş (ELGS) with 18,75\%. In comparison with the situation of assets structure rates who did not register good values, the liabilities structure rates have registered in a very high measure normal values. For example, for the rate of global indebtedness, more than half the enterprises have registered normal values. We can give as example BERMAS S.A. (BRM) having the 21,35\% share, ROMCARBON S.A. (ROCE) with $40,92 \%$, in conclusion values smaller than $66 \%$, so that we can state that this indicator reflects the favourable situation of all enterprises registering normal values. The same with the global indebtedness rate, the global financial autonomy rate registers most normal values for the economic unities, for example S.C. FONDUL PROPRIETATEA S.A.-Bucharest (FP) with 99,49\% and ALUMIL ROM INDUSTRY S.A. (ALU) holding 80,90\% share. We may state that values exceed $30 \%$, which supposes the fact that the financial autonomy premise of the respective companies is insured.

In comparison with the assets and liabilities structure rates registering the percentages determined in tables 1 and 2, from the point of view of issuers according to stock capitalization, the greatest capitalization, namely 31.691908 lei, is held by MECANICA Ceahlău (MECF), followed at short distance by BOROMIR PROD S.A. Buzău (SPCU) with 31.461.992 lei capitalization, and the lowest capitalization, of 900.969 lei belonging to MJ MAILLIS România S.A. (MJM), values that were extracted from the Bucharest Stock Exchange website, in the Top 100 issuers according to capitalization, for the last 3 months, site that was accessed on 01.04.2013.

In conclusion, the calculated structure rates, based on data taken from the patrimonial balance sheet, supposed determination of the enterprises financial position, studied by comparing rates with normal values in industry.

\section{References:}

1. Achim M. V., 2009. Analiză economico-financiară, Risoprint Publishing House, Cluj Napoca,

2. Berheci M., 2010. Valorificarea raportărilor financiare. Sinteze contabile: teorie, analize, studii de caz, CECCAR Publishing House, Bucureşti,.

3. Jianu I., 2007. Evaluarea, prezentarea şi analiza performanței întreprinderii, CECCAR Publishing House, Bucureşti.

4. Legea contabilității (The Accouning Law), nr. 82/1991, republicată în Monitorul Oficial nr. $454 / 2008$.

5. Ordinului Ministerului Finanțelor Publice 3055/2011 "Reglementări contabile conforme cu Directiva a IV-a a Comunităților Economice Europene".

6. Petriş R., "Bazele contabilitățiii", (breviar), ediția a III-a, Gorun Publishing House, Iaşi, 2000.

7. Ternisien M., Lire et interpréter les comptes de l $\square$ entreprise, Dunod Publishing House, Paris, 1992.

8. www.bvb.ro 
Annex no. 1

Determination of assets structure rates

\begin{tabular}{|c|c|c|c|c|c|c|c|}
\hline \multirow[b]{2}{*}{ 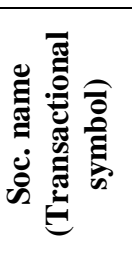 } & \multicolumn{3}{|c|}{ Indicators 2011 -lei- } & \multicolumn{4}{|c|}{ Rate (\%) } \\
\hline & $\begin{array}{l}\text { Non - current } \\
\text { Assets }\end{array}$ & $\begin{array}{l}\text { Current } \\
\text { Assets }\end{array}$ & $\begin{array}{l}\text { Expenses } \\
\text { in advance }\end{array}$ & $\begin{array}{l}\text { I. The non current } \\
\text { assets rate }\end{array}$ & $\begin{array}{l}\text { II. The current assets } \\
\text { rate }\end{array}$ & $\begin{array}{l}\text { III. Expenses in } \\
\text { advance rate }\end{array}$ & Total \\
\hline ALR & 1.496 .637 .226 & 893.905 .503 & 37.931 .787 & 61,63 & 36,81 & 1,56 & $100 \%$ \\
\hline ALT & 117.144 .492 & 58.978 .381 & 96.821 & 66,48 & 33,47 & 0,05 & $100 \%$ \\
\hline ALU & 21.550 .788 & 61.452 .476 & 210.502 & 25,90 & 73,85 & 0,25 & $100 \%$ \\
\hline AMO & 56.675 .423 & 30.217 .815 & 2.533 .528 & 63,38 & 33,79 & 2,83 & $100 \%$ \\
\hline APC & 26.826 .467 & 53.949 .737 & 87.738 & 33,17 & 66,72 & 0,11 & $100 \%$ \\
\hline ARM & 14.646 .848 & 13.586 .558 & 47.418 & 51,80 & 48,04 & 0,16 & $100 \%$ \\
\hline ARS & 75.459 .594 & 85.100 .086 & 0 & 47,00 & 53,00 & 0 & $100 \%$ \\
\hline ART & 473.477 .735 & 425.860 .277 & 2.120 .934 & 52,52 & 47,24 & 0,24 & $100 \%$ \\
\hline ARTE & 61.922 .741 & 89.455 .360 & 337.580 & 40,82 & 58,96 & 0,22 & $100 \%$ \\
\hline ATB & 175.363 .858 & 273.646 .635 & 302.678 & 39,03 & 60,90 & 0.07 & $100 \%$ \\
\hline BCM & 27.520 .502 & 13.955 .300 & 305.561 & 65,87 & 33,40 & 0,73 & $100 \%$ \\
\hline $\mathrm{BIO}$ & 68.660 .609 & 115.969 .010 & 288.892 & 37,13 & 62,71 & 0,16 & $100 \%$ \\
\hline BRK & 46.779 .225 & 46.283 .781 & 0 & 50,27 & 49,73 & 0 & $100 \%$ \\
\hline BRM & 16.036 .533 & 13.283 .808 & 388 & 54,69 & 45,31 & 0 & $100 \%$ \\
\hline BVB & 28.668 .774 & 77.465 .220 & 0 & 27,01 & 72,99 & 0 & $100 \%$ \\
\hline CAOR & 78.958 .057 & 11.509 .977 & 273.197 & 87,01 & 12,69 & 0,30 & $100 \%$ \\
\hline $\mathrm{CBC}$ & 55.273 .102 & 18.278 .400 & 137.735 & 75,01 & 24,80 & 0,19 & $100 \%$ \\
\hline CEON & 152.819 .945 & 11.272 .273 & 17.043 & 93,12 & 6,87 & 0,01 & $100 \%$ \\
\hline CGC & 44.360 .648 & 13.088 .163 & 15.186 & 77,20 & 22,78 & 0,02 & $100 \%$ \\
\hline CMCM & 263.863 .501 & 12.575 .625 & 214.662 & 95,38 & 4,54 & 0,08 & $100 \%$ \\
\hline CMF & 29.205 .292 & 54.222 .451 & 0 & 35,01 & 64,99 & 0 & $100 \%$ \\
\hline CMP & 329.181 .211 & 164.021 .915 & 762.863 & 66,64 & 33,21 & 0,15 & $100 \%$ \\
\hline CNTE & 3.529 .881 & 8.244 .462 & 10.275 & 29,95 & 69,96 & 0,09 & $100 \%$ \\
\hline COMI & 105.092 .659 & 83.496 .669 & 398.093 & 55,61 & 44,18 & 0,21 & $100 \%$ \\
\hline $\mathrm{COS}$ & 203.225 .976 & 291.770 .633 & 4.903 .409 & 40,65 & 58,37 & 0.98 & $100 \%$ \\
\hline COTR & 145.519 .689 & 37.044 .234 & 92.620 & 79,67 & 20,28 & 0,05 & $100 \%$ \\
\hline DAFR & 299.794 .782 & 138.826 .875 & 106.043 & 68,33 & 31,64 & 0,03 & $100 \%$ \\
\hline
\end{tabular}


Annales Universitatis Apulensis Series Oeconomica, 15(2), 2013, 570-579

\begin{tabular}{|c|c|c|c|c|c|c|c|}
\hline ECT & 7.104 .844 & 7.672 .353 & 0 & 48,08 & 51,92 & 0 & $100 \%$ \\
\hline EFO & 230.196 .175 & 21.485 .057 & 9.836 & 91,46 & 8,54 & 0 & $100 \%$ \\
\hline ELGS & 8.699 .482 & 37.688 .519 & 8.207 & 18,75 & 81,23 & 0,02 & $100 \%$ \\
\hline ELJ & 11.733 .505 & 17.739 .263 & 166.296 & 39,59 & 59,85 & 0,56 & $100 \%$ \\
\hline ELMA & 233.495 .625 & 88.128 .641 & 1.749 .402 & 72,21 & 27,25 & 0,54 & $100 \%$ \\
\hline ENP & 5.425 .826 & 26.245 .289 & 51.190 & 17,10 & 82,74 & 0,16 & $100 \%$ \\
\hline EPT & 304.404 .885 & 128.014 .614 & 0 & 70,40 & 29,60 & 0 & $100 \%$ \\
\hline FP & 10.627 .878 .080 & 549.198 .812 & 28.412 & 95,09 & 4,91 & 0 & $100 \%$ \\
\hline IMP & 90.810 .963 & 317.322 .814 & 218.690 & 22,24 & 77,71 & 0,05 & $100 \%$ \\
\hline MECF & 24.743 .718 & 23.679 .826 & 68.959 & & & & \\
\hline MEF & 15.674 .226 & 24.990 .490 & 644 & 38,55 & 61,45 & 0 & $100 \%$ \\
\hline MJM & 22.657 .811 & 11.119 .261 & 53.860 & 66,97 & 32,87 & 0,16 & $100 \%$ \\
\hline $\begin{array}{l}\text { MPN } \\
\text { (2010) }\end{array}$ & 269.563 .485 & 112.535 .846 & 2.141 .056 & 70,15 & 29,29 & 0,56 & $100 \%$ \\
\hline NEP & 229.454 .757 & 14.951 .837 & 0 & 93,88 & 6,12 & 0 & $100 \%$ \\
\hline OIL & 361.881 .727 & 16.355 .067 & 122.821 & 95,65 & 4,32 & 0,03 & $100 \%$ \\
\hline OLT & 1.876 .114 .299 & 318.964 .226 & 3.345 .234 & 85,34 & 14,51 & 0,15 & $100 \%$ \\
\hline PEI & 10.971 .825 & 57.865 .204 & 10.716 & 15,94 & 88,05 & 0,01 & $100 \%$ \\
\hline PPL & 9.285 .759 & 41.055 .289 & 21.521 & 18,44 & 81,52 & 0,04 & $100 \%$ \\
\hline PREH & 198.191 .648 & 63.909 .167 & 25.248 & 75,61 & 24,38 & 0,01 & $100 \%$ \\
\hline PTR & 60.340 .022 & 82.471 .754 & 217.468 & 42,19 & 57,66 & 0,15 & $100 \%$ \\
\hline RMAH & 36.303 .710 & 126.618 .992 & 20.020 & 22,28 & 77,71 & 0,01 & $100 \%$ \\
\hline ROCE & 195.268.211 & 39.411 .197 & 176.548 & 83,14 & 16,78 & 0,08 & $100 \%$ \\
\hline $\mathrm{RPH}$ & 70.021 .302 & 317.537 .723 & 788.007 & 18,03 & 81,77 & 0,20 & $100 \%$ \\
\hline RRC & 4.300 .764 .385 & $\begin{array}{c}2.261 .247 .23 \\
2\end{array}$ & 1.555 .268 & 65,53 & 34,45 & 0,02 & $100 \%$ \\
\hline RTRA & 21.786 .116 & 26.070 .693 & 6.254 & 45,52 & 54,47 & 0,01 & $100 \%$ \\
\hline SCD & 85.823 .334 & 261.579 .306 & 353.097 & 24,68 & 75,22 & 0,10 & $100 \%$ \\
\hline SIF1 & 596.381 .775 & 137.346 .746 & 201.142 & 81,26 & 18,71 & 0,03 & $100 \%$ \\
\hline SIF2 & 551.509 .546 & 139.435 .510 & 63.441 & 79,81 & 20,18 & 0,01 & $100 \%$ \\
\hline SIF3 & 749.614 .298 & 137.739 .263 & 104.646 & 84,47 & 15,52 & 0,01 & $100 \%$ \\
\hline SIF4 & 1.137 .307 .947 & 185.406 .205 & 20.057 & 85,98 & 14,02 & 0 & $100 \%$ \\
\hline SIF5 & 731.252 .375 & 83.497 .496 & 232.752 & 89,73 & 10,24 & 0,03 & $100 \%$ \\
\hline SNO & 41.518 .154 & 54.945 .563 & 43.590 & 43,02 & 56,93 & 0,05 & $100 \%$ \\
\hline SNP & 28.568 .337 .614 & $\begin{array}{c}5.135 .942 .84 \\
6 \\
\end{array}$ & 115.273 .240 & 84,47 & 15,19 & 0,34 & $100 \%$ \\
\hline SOCP & 56.451 .421 & 50.304 .631 & 39.720 & 52,86 & 47,10 & 0,04 & $100 \%$ \\
\hline SPCU & 123.780 .263 & 32.574 .363 & 2.236 .103 & 78,05 & 20,54 & 1,41 & $100 \%$ \\
\hline
\end{tabular}


Annales Universitatis Apulensis Series Oeconomica, 15(2), 2013,

\begin{tabular}{|c|c|c|c|c|c|c|c|}
\hline SRT & 14.159 .841 & 17.081 .605 & 0 & 45,32 & 54,68 & 0 & $100 \%$ \\
\hline STIB & 227.785 .195 & 152.818 .835 & 260.639 & 59,81 & 40,12 & 0.07 & $100 \%$ \\
\hline STZ & 171.044 .907 & 6.859 .089 & 1.221 .522 & 95,49 & 3,83 & 0,68 & $100 \%$ \\
\hline TBM & 121.135 .007 & 40.377 .827 & 18.606 & 74,99 & 25,00 & 0,01 & $100 \%$ \\
\hline TEL & 3.667 .984 .393 & $\begin{array}{c}1.546 .621 .69 \\
2\end{array}$ & 1.199 .743 & 70,33 & 29,65 & 0,02 & $100 \%$ \\
\hline TGN & 3.402 .786 .965 & 684.878 .301 & 1.371 .954 & 83,22 & 16,75 & 0,03 & $100 \%$ \\
\hline TRP & 156.800 .070 & 79.472 .041 & 384.796 & 66,26 & 33,58 & 0,16 & $100 \%$ \\
\hline TUFE & 178.306 .529 & 15.767 .135 & 68.575 & 91,84 & 8,12 & 0,04 & $100 \%$ \\
\hline UAM & 50.656 .972 & 46.193 .959 & 0 & 52,30 & 47,70 & 0 & $100 \%$ \\
\hline UZT & 74.782 .776 & 89.744 .848 & 618.480 & 45,28 & 54,34 & 0,38 & $100 \%$ \\
\hline VESY & 20.263 .039 & 23.094 .553 & 4.626 & 46,73 & 53,26 & 0,01 & $100 \%$ \\
\hline VNC & 161.444 .013 & 62.042 .704 & 1.199 .518 & 71,85 & 27,61 & 0,54 & $100 \%$ \\
\hline
\end{tabular}

Annex no. 2

Determination of assets structure rates

\begin{tabular}{|c|c|c|c|c|c|c|c|c|c|c|}
\hline \multirow{3}{*}{ 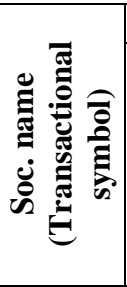 } & \multicolumn{3}{|c|}{ Indicators 2011} & \multicolumn{2}{|c|}{-lei- } & \multicolumn{3}{|r|}{ Rate } & \multicolumn{2}{|l|}{$-\%-$} \\
\hline & \multirow[t]{2}{*}{ Equity } & \multirow[t]{2}{*}{$\begin{array}{l}\text { Long-term } \\
\text { detbts }\end{array}$} & \multirow[t]{2}{*}{ Short-term debts } & \multirow[t]{2}{*}{ Commissions } & \multirow[t]{2}{*}{$\begin{array}{l}\text { In-advance } \\
\text { incomes }\end{array}$} & $\begin{array}{l}\text { I. The rate of } \\
\text { global liability }\end{array}$ & $\begin{array}{l}\text { II. The } \\
\text { rate of } \\
\text { global } \\
\text { financial } \\
\text { autonomy }\end{array}$ & $\begin{array}{c}\text { III. The } \\
\text { rate of } \\
\text { commissio } \\
\text { ns }\end{array}$ & $\begin{array}{l}\text { IV. The } \\
\text { rate of in- } \\
\text { advance } \\
\text { incomes }\end{array}$ & Total \\
\hline & & & & & & $\square 66 \%$ & $\square 33 \%$ & & & \\
\hline ALR & 1.553 .478 .084 & 572.823 .176 & 237.136 .574 & 56.353 .428 & 8.683 .254 & 33,35 & 63,97 & 2,32 & 0,36 & $100 \%$ \\
\hline ALT & 108.817 .664 & 2.601 .708 & 56.963 .602 & 0 & 7.836 .720 & 33,80 & 61,75 & 0 & 4,45 & $100 \%$ \\
\hline ALU & 67.317 .750 & 0 & 15.761 .595 & 74.572 & 59.849 & 18,94 & 80,90 & 0,09 & 0,07 & $100 \%$ \\
\hline AMO & 65.085 .786 & 0 & 19.772 .384 & 4.568 .596 & 0 & 22,11 & 72,78 & 5,11 & 0 & $100 \%$ \\
\hline APC & 61.770 .689 & 0 & 18.181 .627 & 832.860 & 78.766 & 22,48 & 76,39 & 1,03 & 0,10 & $100 \%$ \\
\hline ARM & 174.910 & 21.598 .500 & 5.991 .786 & 261.401 & 254.227 & 97,56 & 0,62 & 0,92 & 0,90 & $100 \%$ \\
\hline ARS & 102.543 .403 & 0 & 18.119 .220 & 36.223 .697 & 3.673 .360 & 11,28 & 63,87 & 22,56 & 2,29 & $100 \%$ \\
\hline ART & 428.779 .733 & 303.629 .332 & 164.070 .044 & 4.938 .135 & 41.702 & 51,88 & 47,57 & 0,55 & 0 & $100 \%$ \\
\hline ARTE & 78.885 .933 & 33.936 & 68.937 .111 & 0 & 3.858 .701 & 45,46 & 52,00 & 0 & 2,54 & $100 \%$ \\
\hline ATB & 287.058 .407 & 0 & 142.722 .089 & 14.594 .637 & 4.938 .038 & 31,76 & 63,89 & 3,25 & 1,10 & $100 \%$ \\
\hline
\end{tabular}


Annales Universitatis Apulensis Series Oeconomica, 15(2), 2013, 570-579

\begin{tabular}{|c|c|c|c|c|c|c|c|c|c|c|}
\hline BCM & 41.188 .707 & 0 & 492.398 & 100.258 & 0 & 1,18 & 98,58 & 0,24 & 0 & $100 \%$ \\
\hline $\mathrm{BIO}$ & 153.957 .996 & 402.687 & 26.547 .462 & 4.010 .366 & 0 & 14,57 & 83,26 & 2,17 & 0 & $100 \%$ \\
\hline BRK & 74.982 .177 & 83.635 & 10.441 .582 & 7.452 .149 & 103.463 & 11,31 & 80,57 & 8,01 & 0,11 & $100 \%$ \\
\hline BRM & 23.061 .192 & 0 & 6.259 .537 & 0 & 0 & 21,35 & 78,65 & 0 & 0 & $100 \%$ \\
\hline BVB & 102.031 .008 & 0 & 2.598 .705 & 766.743 & 737.538 & 2,45 & 96,13 & 0,72 & 0,70 & $100 \%$ \\
\hline CAOR & 68.265 .291 & 11.402 .695 & 8.619 .700 & 2.276 .145 & 177.400 & 22,07 & 75,23 & 2,50 & 0,20 & $100 \%$ \\
\hline $\mathrm{CBC}$ & 64.750 .678 & 158.376 & 8.774 .901 & 1.111 & 4.171 & 12,12 & 87,87 & 0 & 0,01 & $100 \%$ \\
\hline CEON & 28.556 .970 & 74.935 .959 & 53.838 .543 & 5.240 .743 & 1.537 .046 & 78,47 & 17,40 & 3,19 & 0,94 & $100 \%$ \\
\hline $\mathrm{CGC}$ & -6.250 .349 & 0 & 63.623 .314 & 91.032 & 0 & 110,72 & $-10,88$ & 0,16 & 0 & $100 \%$ \\
\hline CMCM & 262.717 .089 & 6.443 .536 & 6.945 .341 & 0 & 547.822 & 4,84 & 94,96 & 0 & 0,20 & $100 \%$ \\
\hline $\mathrm{CMF}$ & 31.673 .038 & 0 & 50.215 .466 & 791.322 & 747.917 & 60,19 & 37,96 & 0,95 & 0,90 & $100 \%$ \\
\hline CMP & 292.562 .890 & 76.947 .904 & 99.869 .085 & 1.260 .000 & 23.326 .110 & 35,80 & 59,23 & 0,25 & 4,72 & $100 \%$ \\
\hline CNTE & 10.353 .981 & 14.849 & 1.415 .788 & 0 & 0 & 12,14 & 87,86 & 0 & 0 & $100 \%$ \\
\hline COMI & 133.194 .377 & 12.546 .041 & 42.147 .476 & 1.099 .527 & 0 & 28,94 & 70,48 & 0,58 & 0 & $100 \%$ \\
\hline $\mathrm{COS}$ & -92.021 .529 & 990.135 & 589.348 .406 & 1.583 .006 & 0 & 118,09 & $-18,41$ & 0,32 & 0 & $100 \%$ \\
\hline COTR & 129.964 .290 & 30.302 .669 & 20.337 .347 & 1.760 .651 & 291.586 & 27,73 & 71,15 & 0,96 & 0,16 & $100 \%$ \\
\hline DAFR & 157.590 .102 & 167.042 .255 & 113.120 .356 & 974.987 & 0 & 63,86 & 35,92 & 0,22 & 0 & $100 \%$ \\
\hline ECT & 11.698 .064 & 0 & 3.059 .113 & 0 & 20.020 & 20,70 & 79,16 & 0 & 0,14 & $100 \%$ \\
\hline EFO & 232.964 .488 & 1.137 .324 & 15.716 .221 & 0 & 1.873 .035 & 6,70 & 92,56 & 0 & 0,74 & $100 \%$ \\
\hline ELGS & 26.260 .086 & 0 & 19.975 .509 & 0 & 160.613 & 43,05 & 56,60 & 0 & 0,35 & $100 \%$ \\
\hline ELJ & 25.631 .133 & 868.085 & 2.760 .116 & 345.131 & 34.599 & 12,24 & 86,48 & 1,16 & 0,12 & $100 \%$ \\
\hline ELMA & 269.148 .045 & 1.558 .086 & 45.825 .385 & 801.531 & 6.040 .621 & 14,65 & 83,23 & 0,25 & 1,87 & $100 \%$ \\
\hline ENP & 9.936 .674 & 3.507 .294 & 17.831 .316 & 447.021 & 0 & 67,27 & 31,32 & 1,41 & 0 & $100 \%$ \\
\hline EPT & 20.898 .016 & 278.383 .786 & 127.240 .953 & 5.813 .837 & 82.907 & 93,80 & 4,83 & 1,35 & 0,02 & $100 \%$ \\
\hline $\mathrm{FP}$ & 11.120 .700 .702 & 0 & 42.206 .773 & 14.197 .829 & 0 & 0,38 & 99,49 & 0,13 & 0 & $100 \%$ \\
\hline IMP & 296.828 .111 & 64.696 .047 & 40.564 .811 & 2.409 .656 & 3.853 .842 & 25,78 & 72,69 & 0,59 & 0,94 & $100 \%$ \\
\hline MECF & 38.283 .152 & 4.192 .238 & 5.948 .155 & 0 & 104.037 & & & & & \\
\hline MEF & 34.928 .783 & 1.506 .630 & 3.559 .147 & 0 & 670.800 & 12,46 & 85,89 & 0 & 1,65 & $100 \%$ \\
\hline MJM & -8.607 .446 & 0 & 42.277 .382 & 0 & 160.996 & 124,96 & $-25,44$ & 0 & 0,48 & $100 \%$ \\
\hline $\begin{array}{l}\text { MPN } \\
(2010)\end{array}$ & 134.185 .978 & 0 & 247.621 .448 & 270.045 & 2.162 .916 & 64,44 & 34,92 & 0,07 & 0,57 & $100 \%$ \\
\hline NEP & 243.173 .015 & 1.145 .997 & 87.582 & 0 & 0 & 99,50 & 0,50 & 0 & 0 & $100 \%$ \\
\hline OIL & 345.226 .806 & 4.263 .066 & 26.025 .160 & 2.291 .538 & 553.045 & 8,01 & 91,24 & 1,36 & 0,14 & $100 \%$ \\
\hline OLT & -826.884 .427 & 986.004 .655 & 1.553.448.319 & 29.851 .465 & 456.003 .747 & 115,51 & $-37,61$ & 1,36 & 20,74 & $100 \%$ \\
\hline PEI & 13.013 .030 & 22.910 .779 & 26.917 .309 & 6.002 .265 & 4.362 & 72,37 & 18,90 & 8,72 & 0,01 & $100 \%$ \\
\hline PPL & 47.572 .517 & 0 & 2.790 .052 & 0 & 0 & 5,54 & 94,46 & 0 & 0 & $100 \%$ \\
\hline PREH & 202.531 .399 & 25.605 .300 & 33.863 .201 & 0 & 126.163 & 22,69 & 77,26 & 0 & 0,05 & $100 \%$ \\
\hline
\end{tabular}




\begin{tabular}{|c|c|c|c|c|c|c|c|c|c|c|}
\hline PTR & 128.436 .335 & 0 & 11.607 .647 & 2.854 .884 & 130.378 & 8,91 & 89,80 & 0,09 & 1,20 & $100 \%$ \\
\hline RMAH & 39.835 .319 & 537.635 & 120.614 .152 & 1.955 .616 & 0 & 74,35 & 24,45 & 1,20 & 0 & $100 \%$ \\
\hline ROCE & 133.187 .047 & 27.393 .645 & 68.709 .356 & 0 & 5.565 .908 & 40,92 & 56,71 & 0 & 2,37 & $100 \%$ \\
\hline RPH & 91.212 .485 & 5.061 .758 & 291.992 .463 & 54.314 & 26.012 & 76,49 & 23,49 & 0,01 & 0,01 & $100 \%$ \\
\hline $\mathrm{RRC}$ & -134.091 .000 & 0 & 6.617 .973 .868 & 79.684 .017 & 0 & 100,83 & $-2,04$ & 1,21 & 0 & $100 \%$ \\
\hline RTRA & 23.037 .153 & 1.404 .554 & 23.416 .657 & 0 & 4.699 & 51,86 & 48,13 & 0 & 0,01 & $100 \%$ \\
\hline SCD & 256.395 .838 & 0 & 78.422 .152 & 12.859 .023 & 78.724 & 22,55 & 73,73 & 3,70 & 0,02 & $100 \%$ \\
\hline SIF1 & 642.598 .332 & 0 & 37.863 .920 & 53.467 .411 & 0 & 5,16 & 87,55 & 7,29 & 0 & $100 \%$ \\
\hline SIF2 & 566.155 .402 & 0 & 57.284 .930 & 67.558 .684 & 9.480 & 8,29 & 81,93 & 9,78 & 0 & $100 \%$ \\
\hline SIF3 & 769.314 .328 & 0 & 46.092 .722 & 72.051 .157 & 0 & 5,19 & 86,69 & 8,12 & 0 & $100 \%$ \\
\hline SIF4 & 1.137 .521 .392 & 0 & 95.621 .170 & 89.591 .647 & 0 & 7,22 & 86,00 & 6,77 & 0 & $100 \%$ \\
\hline SIF5 & 652.841 .780 & 0 & 104.201 .524 & 57.939 .319 & 0 & 12,79 & 80,10 & 7,11 & 0 & $100 \%$ \\
\hline SNO & 88.410 .039 & 0 & 7.767 .081 & 330.187 & 0 & 8,05 & 91,61 & 0,34 & 0 & $100 \%$ \\
\hline SNP & 18.890 .892 .162 & 2.255 .228 .600 & 4.677 .942 .732 & 7.962 .682 .564 & 32.807 .642 & 20,50 & 55,86 & 23,54 & 0,10 & $100 \%$ \\
\hline SOCP & 99.800 .086 & 2.299 .916 & 3.771 .610 & 740.560 & 183.600 & 5,69 & 93,45 & 0,69 & 0,17 & $100 \%$ \\
\hline SPCU & 128.786 .567 & 11.047 .413 & 18.648 .416 & 0 & 108.333 & 18,72 & 81,21 & 0 & 0,07 & $100 \%$ \\
\hline SRT & 13.152 .686 & 5.035 .956 & 12.813 .608 & 0 & 239.196 & 57,13 & 42,10 & 0 & 0,77 & $100 \%$ \\
\hline STIB & 260.042 .571 & 7.199 .501 & 111.897 .337 & 1.567 .585 & 157.675 & 31,27 & 68,28 & 0,41 & 0,04 & $100 \%$ \\
\hline STZ & 167.543 .309 & 4.967 .730 & 6.263 .673 & 0 & 350.806 & 6,27 & 93,53 & 0 & 0,20 & $100 \%$ \\
\hline TBM & 67.520 .493 & 23.500 .980 & 66.562 .407 & 2.795 .182 & 1.152 .378 & 55,76 & 41,80 & 1,73 & 0,71 & $100 \%$ \\
\hline TEL & 2.468 .483 .557 & 943.492 .527 & 1.390 .691 .247 & 47.945 .791 & 365.192 .706 & 44,75 & 47,33 & 0,92 & 7,00 & $100 \%$ \\
\hline TGN & 3.262 .877 .964 & 75.147 .643 & 358.127 .194 & 42.427 .376 & 350.457 .043 & 10,60 & 79,79 & 1,04 & 8,57 & $100 \%$ \\
\hline TRP & 130.073 .871 & 35.999 .810 & 66.806 .132 & 3.777 .094 & 0 & 43,44 & 54,96 & 1,60 & 0 & $100 \%$ \\
\hline TUFE & 173.052 .703 & 17.119 .011 & 3.740 .372 & 39.063 & 191.090 & 10,74 & 89,14 & 0,02 & 0,10 & $100 \%$ \\
\hline UAM & 46.546 .752 & 7.310 .786 & 42.857 .050 & 0 & 136.343 & 51,80 & 48,06 & 0 & 0,14 & $100 \%$ \\
\hline UZT & 86.197 .982 & 67.666 .864 & 9.713 .745 & 262.238 & 1.305 .275 & 46,86 & 52,19 & 0,16 & 0,79 & $100 \%$ \\
\hline VESY & 18.597 .132 & 153.352 & 24.580 .567 & 0 & 31.167 & 57,04 & 42,89 & 0 & 0,07 & $100 \%$ \\
\hline $\mathrm{VNC}$ & 88.234 .850 & 62.321 .559 & 63.144 .123 & 0 & 10.985 .703 & 39,27 & 55,84 & 0 & 4,89 & $100 \%$ \\
\hline
\end{tabular}

